University of Wollongong

Research Online

Faculty of Engineering and Information

Faculty of Engineering and Information

Sciences - Papers: Part B

Sciences

2018

Axial Compressive Behavior of Steel Equal Angle Section-Reinforced Square High-Strength Concrete Column

Ayoob Ibrahim

University of Wollongong, aaii884@uowmail.edu.au

M Neaz Sheikh

University of Wollongong, msheikh@uow.edu.au

Muhammad N. S Hadi

University of Wollongong, mhadi@uow.edu.au

Follow this and additional works at: https://ro.uow.edu.au/eispapers1

Part of the Engineering Commons, and the Science and Technology Studies Commons

Research Online is the open access institutional repository for the University of Wollongong. For further information contact the UOW Library: research-pubs@uow.edu.au 


\title{
Axial Compressive Behavior of Steel Equal Angle Section-Reinforced Square High-Strength Concrete Column
}

\author{
Abstract \\ A new method of reinforcing concrete columns with steel equal angle (SEA) sections has been \\ investigated. A total of 12 square high-strength concrete (HSC) column specimens (with $210 \mathrm{~mm}$ [8.26 \\ in.] sides and $600 \mathrm{~mm}$ [23.62 in.] height) reinforced longitudinally with either steel bars or SEA sections \\ were cast and tested. The lateral tie spacing of specimens varied from 50 to $400 \mathrm{~mm}$ (1.96 to $15.74 \mathrm{in}$.). \\ The influences of the type of longitudinal reinforcement and the spacing of lateral ties on the behavior of \\ HSC specimens under axial compression were investigated. Experimental results showed that the use of \\ the SEA sections as longitudinal reinforcements in HSC column specimens led to significant \\ improvements in the axial load-carrying capacity and ductility compared to the corresponding HSC \\ column specimens reinforced longitudinally with steel bars.

\section{Disciplines} \\ Engineering | Science and Technology Studies

\section{Publication Details} \\ Ibrahim, A. A., Sheikh, M. \& Hadi, M. N. S. (2018). Axial Compressive Behavior of Steel Equal Angle \\ Section-Reinforced Square High-Strength Concrete Column. Aci Structural Journal, 115 (5), 1431-1442.
}


Biography:

6 Ayoob A. Ibrahim is a PhD candidate in the School of Civil, Mining \& Environmental Engineering

7 University of Wollongong, Australia. He received his BS from University of Babylon, Iraq, in 2002 and MS from University of Babylon, in 2005. His research interests include steel fiber reinforced concrete and members under cyclic loading.

M. Neaz Sheikh is an Associate Professor in the School of Civil, Mining \& Environmental Engineering, University of Wollongong, Australia. He received his BSc (Civil Engineering) from Chittagong University of Engineering and Technology (CUET), Bangladesh, and his MPhil and PhD from the University of Hong Kong, China. His research interests include earthquake engineering, concrete structures, and application of advanced composite materials in civil infrastructure.

ACI member Muhammad N. S. Hadi is an Associate Professor in the School of Civil, Mining \& Environmental Engineering, University of Wollongong, Australia. He received his BS and MS from the University of Baghdad, Iraq, in 1977 and 1980, respectively, and his PhD from the University of Leeds, UK, in 1989. His research interests include analysis and design of concrete structures.

\section{ABSTRACT}

A new method of reinforcing concrete columns with steel equal angle (SEA) sections has been investigated. A total of 12 square High Strength Concrete (HSC) column specimens (210 mm (8.26 in.) sides and $600 \mathrm{~mm}$ (23.62 in.) height) reinforced longitudinally with either steel bars or SEA sections were cast and tested. The lateral tie spacing of specimens varied from $50 \mathrm{~mm}$ (1.96 in.) to $400 \mathrm{~mm}$ (15.74 in.). The influences of the type of longitudinal reinforcement and the spacing of lateral ties on the behavior of HSC specimens under axial compression were investigated. 
Experimental results showed that the use of the SEA sections as longitudinal reinforcements in HSC

column specimens led to significant improvements in the axial load carrying capacity and ductility compared to the corresponding HSC column specimens reinforced longitudinally with steel bars.

Keywords: Reinforced concrete; Columns; Steel Equal Angle; Tie spacing; Axial load; Buckling; Ductility.

\section{INTRODUCTION}

Composite columns are usually used in high-rise buildings due to high strength, stiffness, ductility, and seismic resistance of composite columns. ${ }^{1,2}$ There are two main types of composite columns: concrete encased steel section and concrete filled hollow steel section. Encased composite columns (concrete encased steel section) are being increasingly used as structural members because of their higher fire resistance compared to the concrete filled hollow steel sections, which require protection against fire. ${ }^{3}$ Also, in the encased composite column, the local buckling resistance of encased steel section is higher. ${ }^{4}$ In addition, the use of encased steel sections in composite columns reduces the cross-sectional dimensions and increases the strength-to-weight ratio of the columns. ${ }^{2}$ According to a detailed literature review carried out herein, no study is available in the literature that deals with high strength concrete (HSC) columns reinforced with steel equal angle (SEA) sections.

The use of high-strength concrete (HSC) in the buildings has increased in recent years. ${ }^{5-7}$ However, the ductility of HSC is lower than the ductility of normal strength concrete (NSC). ${ }^{8-11}$ Also, HSC columns under concentric axial compression experience premature concrete cover spalling, which considerably decreases the axial strength of columns. ${ }^{12}$ Therefore, the ductility and the strength of HSC columns were extensively investigated. ${ }^{13-15}$ In general, more lateral reinforcement is required in HSC columns than in NSC columns to achieve a similar ductility. ${ }^{16,17}$

Concrete columns are commonly reinforced longitudinally with conventional steel bars and laterally with either ties or helices. For square concrete columns reinforced with lateral ties, the area of the 
effectively confined concrete core is less than the total area of the concrete core, which results in

54 lower strength and ductility of the square RC columns. ${ }^{18}$ In this study, Steel Equal Angle (SEA) sections were used as longitudinal reinforcement for square HSC columns. The SEA sections have been widely used in the construction of steel structures. ${ }^{19-21}$ However, no previous study investigated the use of SEA sections in reinforcing HSC columns. The use of SEA sections instead of conventional steel bars in the square HSC columns can increase the confinement of the concrete core, which may increase the ductility of columns under axial compression. In addition, the SEA section has a higher second moment of area than the conventional steel bar for the same cross-sectional area, which may increase the buckling load of the longitudinal reinforcement. As a result, less lateral ties may be required in HSC columns reinforced with SEA sections than in HSC columns reinforced with steel bars. This study investigates the influence of the SEA sections on the failure modes, maximum axial load, confinement efficiency and post-peak axial load-axial deformation behavior of the square HSC columns.

\section{RESEARCH SIGNIFIANCE}

One of the main problems associated with the use of HSC in the construction of reinforced concrete columns is that the ductility of HSC columns is usually lower than the ductility of NSC columns. To increase the ductility of HSC columns under axial compression, this study investigates the effectiveness of the use of SEA sections, instead of steel bars, as longitudinal reinforcements in square HSC columns. The findings of this study can be used to evaluate the feasibility of reinforcing square HSC columns with longitudinal SEA sections.

\section{EXPERIMENTAL PROGRAM}

\section{Specimen Details}

The experimental program aimed at investigating the influence of the longitudinal reinforcement 
HSC column specimens under axial compression. A total of 12 square HSC column specimens with $210 \mathrm{~mm} \times 210 \mathrm{~mm}(8.26$ in. $\times 8.26$ in. $)$ cross-section and $600 \mathrm{~mm}(23.62 \mathrm{in}$.$) height were cast and$ tested under concentric axial compression. The tested specimens were divided into three groups of four specimens (Table 1). The tie spacing in each group of specimens varied from $50 \mathrm{~mm}$ (1.96 in.) to $400 \mathrm{~mm}$ (15.74 in.) (Fig. 1). The specimens in the first group (Group B) served as the reference specimens and were reinforced longitudinally with four N12 steel bars (12 mm (0.47 in.) diameter deformed steel bars with $500 \mathrm{MPa}(72.51 \mathrm{ksi})$ nominal yield tensile strength) and laterally with R10 steel bars (10 mm (0.39 in.) diameter plain steel bars with $250 \mathrm{MPa}(36.25 \mathrm{ksi})$ nominal yield tensile strength). In the second group (Group A30), the specimens were reinforced longitudinally with four A30 SEA sections (29.1 mm (1.14 in.) leg width and $2.25 \mathrm{~mm}(0.08 \mathrm{in}$.$) thickness with 350 \mathrm{MPa}$ (50.76 ksi) nominal yield tensile strength) and laterally with R10 steel bars. The specimens in the third group (Group A40) were reinforced longitudinally with four A40 SEA sections (39.3 mm (1.54 in.) leg width and $3.7 \mathrm{~mm}(0.14 \mathrm{in}$.) thickness with $450 \mathrm{MPa}(65.27 \mathrm{ksi})$ nominal yield tensile strength) and laterally with R10 steel bars.

The tested column specimens were identified in two parts (Table 1). In the first part, B, A30, and A40 represent N12 steel bar, A30 SEA section and A40 SEA section, respectively. In the second part S50, S100, S200, and S400 represent the tie spacing of $50 \mathrm{~mm}$ (1.96 in.), $100 \mathrm{~mm}$ (3.93 in.), $200 \mathrm{~mm}$ (7.87 in.) and $400 \mathrm{~mm}$ (15.74 in.) at centers, respectively. For instance, Specimen A30-S100 was reinforced longitudinally with four A30 SEA sections and laterally with R10 steel bars having a tie spacing of $100 \mathrm{~mm}(3.93 \mathrm{in}$.$) at centers.$

\section{Material Properties}

The column specimens were cast vertically with ready-mix high strength concrete (HSC) provided by a local supplier. The maximum size of the coarse aggregate was $10 \mathrm{~mm}$. The slump of the concrete, tested according to AS 1012.3.1-14, ${ }^{22}$ was $180 \mathrm{~mm}$, which represented a good workability 
of the concrete. The compressive strength of the concrete was determined by testing three concrete cylinder specimens of $100 \mathrm{~mm}$ (3.93 in.) diameter and $200 \mathrm{~mm}$ (7.87 in.) height according to AS 1012.9-99. ${ }^{23}$ The average 28-day compressive strength of the concrete was $68.5 \mathrm{MPa}(9.93 \mathrm{ksi})$. Three samples from each of N12 bars and R10 bars were tested in tension according to AS 1391$07^{24}$ by using $500 \mathrm{kN}$ (112.40 kip) Instron testing machine in the Structural Engineering Laboratory at the University of Wollongong, Australia. The average yield tensile strengths of N12 and R10 steel bars were $556 \mathrm{MPa}(80.64 \mathrm{ksi})$ and $323 \mathrm{MPa}$ (46.84 ksi), respectively.

Two different steel equal angle (SEA) sections were used in this study. The SEA sections were supplied by OneSteel. ${ }^{25}$ The nominal and measured dimensions of the SEA sections are reported in Table 2. For each SEA section, tensile coupon specimens were taken from the flat portion of the SEA section. Three samples from each of A30 and A40 SEA sections were tested according to AS $1391-07^{24}$ by using $500 \mathrm{kN}$ (112.40 kip) Instron testing machine. The average yield tensile strengths of A30 and A40 SEA sections were $374 \mathrm{MPa}(54.24 \mathrm{ksi})$ and $473 \mathrm{MPa}(68.60 \mathrm{ksi})$, respectively.

\section{Formwork and Steel Cages}

The formwork used for casting the concrete specimens was fabricated from $17 \mathrm{~mm}(0.66 \mathrm{in}$.$) thick$ plywood. The formwork included two groups of small formwork. Each group was used for casting six specimens. The small formwork was fabricated using two large sheets of plywood (1439 mm $(56.65$ in. $) \times 600 \mathrm{~mm}(23.62$ in. $) \times 17 \mathrm{~mm}(0.66$ in. $))$ and seven small sheets of plywood $(220 \mathrm{~mm}$ $(8.66$ in. $) \times 600 \mathrm{~mm}(23.62$ in. $) \times 17 \mathrm{~mm}(0.66$ in. $))$. The formwork was prepared by placing the plywood sheets together with screws. The longitudinal N12 steel bars and SEA sections were cut into a length of $560 \mathrm{~mm}(22.04 \mathrm{in}$.) to maintain a $20 \mathrm{~mm}(0.78 \mathrm{in}$.) concrete clear cover at the top and the bottom of the specimens. For all specimens, the concrete side cover was $21 \mathrm{~mm}(0.82 \mathrm{in}$.). Square ties were fabricated from R10 steel bars for all specimens. All ties were bent at four corners with a radius of $6 \mathrm{~mm}(0.23 \mathrm{in}$.) so that the ties could be placed over the SEA sections. Also, the ties were bent for 90-degree hooks around one of the longitudinal reinforcement and extended for an overlap of $80 \mathrm{~mm}$ (3.14 in.) at both ends. Each tie was welded at three points on the overlap. The 
spacing of lateral ties was reduced to $40 \mathrm{~mm}(1.57 \mathrm{in}$.) at the end regions to prevent premature failures at the ends (Fig. 1).

Deformed N12 steel bars and smooth SEA sections were used as longitudinal reinforcement. In order to decrease the possible slippage of the SEA sections in the specimens reinforced with SEA sections, two short plain steel bars ( $8 \mathrm{~mm}$ (0.31 in.) diameter and $40 \mathrm{~mm}$ (1.57 in.) long) were welded laterally between the ends of the SEA sections at the top and the bottom. In addition, two short steel bars (16 $\mathrm{mm}(0.62$ in.) diameter and $70 \mathrm{~mm}$ (2.75 in.) length) were welded internally and axially at the top and bottom of each SEA section (Fig. 2). Afterwards, all steel cages were prepared by placing the longitudinal and lateral reinforcement together with steel wires. The concrete was poured into the formwork in three levels. An electric vibrator was used at every level to compact the concrete and remove air bubbles. After 24 hours, the specimens were covered with wet hessian for 28 days to ensure that the specimens remained under moist conditions. The specimens were removed from the formwork after 14 days from casting and kept covered with wet hessian until 28 days from casting.

\section{Instrumentation and Testing Procedure}

The column specimens were instrumented externally to capture the axial deformation of the specimens by using two linear variable differential transducers (LVDTs), as shown in Fig. 3. The LVDTs were attached to the heads of the testing machine at two opposite corners to capture the axial deformation of the specimens (Fig. 3). The axial compression was captured by the internal load cell of the testing machine.

To ensure that the load is applied uniformly, the top surface (rough surface) of the column specimens was capped with a thin layer of high strength plaster. To avoid premature failure of the specimens during testing, the top and the bottom ends of the column specimens were wrapped by two layers of Carbon Fiber Reinforced Polymer (CFRP) sheets with a width of $90 \mathrm{~mm}$ (3.54 in.). The testing of the column specimens was carried out using the $5000 \mathrm{kN}$ (1124.04 kip) Denison compression testing machine in the Structural Engineering Laboratories at the University of Wollongong, Australia. At the beginning of the test, each specimen was preloaded to about $10 \%$ of the expected maximum axial 
156 load of the specimens to prevent any movement in the specimens at the beginning of the test.

157 Afterwards, the test resumed under a displacement controlled concentric axial loading at the rate of

158

159

160

161

162

163

164

165

166

167

168

\section{EXPERIMENTAL RESULTS AND DISCUSSIONS}

\section{Definition of Ductility}

The ductility $(\mu)$ of the tested column specimens was calculated based on the energy absorption capacity of the specimen. The ductility was calculated as the ratio of the area under the axial loadaxial deformation curve up to the ultimate deformation and the area up to the deformation corresponding to the yield axial load. ${ }^{26,27}$

$$
\mu=\frac{A_{u}}{A_{y}}
$$

where $A_{y}$ and $A_{u}$ are the areas under the axial load-axial deformation curves up to the yield deformation $\left(\Delta_{y}\right)$ and up to the ultimate deformation $\left(\Delta_{u}\right)$, respectively. The yield deformation $\left(\Delta_{y}\right)$ is taken as the axial deformation corresponding to the intersection point of an extension line through $75 \%$ of the maximum axial load and the horizontal line from the maximum axial load. ${ }^{28}$ The ultimate deformation was measured as the axial deformation at an axial load equal to $80 \%$ of the maximum axial load in the descending branch of the axial load-axial deformation curve. ${ }^{29}$

\section{Behavior of Column Specimens with 50 mm Tie Spacing}

Specimens B-S50, A30-S50, and A40-S50 were reinforced longitudinally with N12 steel bars, A30 SEA sections and A40 SEA sections, respectively. The spacing of lateral ties for B-S50, A30-S50, and A40-S50 was $50 \mathrm{~mm}$ at centers (center-to-center). All the specimens were tested up to about $20 \%$ of the maximum axial load in the post-peak descending branch of the axial load-axial deformation response. The maximum axial load and corresponding axial deformation of the 
Specimens B-S50, A30-S50 and A40-S50 are reported in Table 3. The maximum axial load represents the axial load carried by the gross concrete cross-sectional area (concrete core and concrete cover) of specimens. Generally, there were some visual cracks prior to the maximum axial load. The first hairline cracks in Specimens B-S50 and A30-S50 appeared at about 88\% and 86\%, respectively, of the corresponding maximum axial loads. These hairline cracks were observed at the mid-height of the specimens. As the axial load increased, the number, length, and width of the cracks increased until the spalling of the concrete cover. The first hairline crack in Specimen A40-S50 was initiated at approximately $90 \%$ of the maximum axial load. This crack occurred at the top one-third height of the specimen and then the cracks appeared at the midheight of the specimen. Afterwards, the number, length and width of the cracks increased until the spalling of the concrete cover. The failure of Specimens B-S50, A30-S50, and A40-S50 was attributed to the spalling of large pieces of the concrete cover, which was followed by outward buckling of longitudinal reinforcement and fracture of lateral ties at welded points, as shown in Fig. 4.

The axial load-axial deformation responses of the specimens with $50 \mathrm{~mm}$ tie spacing are shown in

Fig. 5(a). The maximum axial load carried by the reference Specimen B-S50 was 2929 kN (658.46 kip), which is about $11.6 \%$ higher than the maximum axial load of Specimens A30-S50. The maximum axial load of Specimen B-S50 was higher because the average yield tensile strength of N12 steel bars was $49 \%$ higher than the average yield tensile strength of A30 SEA sections. At the maximum axial loads, the force contribution of N12 steel bars in Specimen B-S50 was 27\% greater than the force contribution of A30 SEA sections in Specimen A30-S50. However, the ductility of Specimen A30-S50 was 44.4\% greater than the ductility of Specimen B-S50. The greater ductility of Specimen A30-S50 indicates that SEA sections increased the area of the effectively confined concrete core after cracking occurred at the cover-core interface. The maximum axial load of Specimens A40-S50 was 2.7\% higher than the maximum axial load of Specimen B-S50. Also, the ductility of Specimen A40-S50 was 50.0\% higher than the ductility of Specimen B-S50. The reason for the higher maximum axial load and the ductility was attributed to the higher confinement to the 
concrete core provided by the A40 SEA sections. Another possible reason was that at the maximum axial load, the force contribution of A40 SEA in Specimen A40-S50 was about 50\% higher than the force contribution of N12 steel bars in Specimen B-S50. The maximum axial load of Specimen A40S50 was $14.6 \%$ higher than the maximum axial load of Specimen A30-S50. The reason for the higher maximum axial load was that at the maximum axial load, the force contribution of A40 SEA in Specimen A40-S50 was about $64 \%$ higher than the force contribution of A30 SEA sections in Specimen A30-S50. Also, Specimen A40-S50 achieved only 3.8\% higher ductility than Specimen A30-S50. The higher ductility for Specimen A40-S50 indicates that the A40 SEA sections were more effective than the A30 SEA sections in confining the concrete core of the specimen.

\section{Behavior of Column Specimens with 100 mm Tie Spacing}

Specimens B-S100, A30-S100, and A40-S100 were reinforced longitudinally with N12 steel bars, A30 SEA sections, and A40 SEA sections, respectively. The spacing of lateral ties for B-S100, A30S100, and A40-S100 was $100 \mathrm{~mm}$ (3.93 in.) at centers. All the specimens were tested up to about $20 \%$ of the maximum axial load in the post-peak descending branch of the axial load-axial deformation response. The test results of Specimens B-S100, A30-S100, and A40-S100 are reported in Table 3. The first hairline cracks in Specimens B-S100 and A30-S100 appeared at approximately $90 \%$ and $82 \%$, respectively, of the corresponding maximum axial loads. The cracks occurred at the top one-third height of the specimens and then the cracks were observed at the midheight of the specimens. Afterwards, the number, length, and width of cracks continued to increase until the concrete cover spalled off. The hairline crack in Specimen A40-S100 was initiated at about $83 \%$ of the maximum axial load. These cracks were observed at the top one-third of the specimen and then the cracks extended downwards and continued to increase in number and size until the spalling of the concrete cover occurred. The failure of Specimens B-S100, A30-S100, and A40-S100 was characterized by the spalling of concrete cover, which was followed by outward buckling of longitudinal reinforcement (Fig. 4). 
231 The axial load-axial deformation responses of the specimens with $100 \mathrm{~mm}$ tie spacing are shown in

232 Fig. 5(b). The maximum axial load of Specimen B-S100 was similar to the maximum axial load of 233 Specimen A30-S100, although, at maximum axial loads, the force contribution of N12 steel bars in 234 Specimen B-S100 was 27\% higher than the force contribution of A30 SEA sections in Specimen maximum axial load, the force contribution of A40 SEA sections in Specimen A40-S100 was about $50 \%$ greater than the force contribution of N12 steel bars in Specimen B-S100. In addition, Specimen A40-S100 achieved $18.8 \%$ higher ductility than Specimen B-S100. The use of SEA sections as longitudinal reinforcement resulted in higher ductility compared to the conventional steel bar reinforced specimens due to the increased confinement of the concrete core provided by the SEA sections. It is noted that specimens reinforced longitudinally with N12 steel bars had about $30 \%$ and $50 \%$ lower confinement effectiveness coefficient $\left(k_{e}\right)$ than specimens reinforced longitudinally with A30 and A40 SEA sections, respectively. The confinement effectiveness coefficient $\left(k_{e}\right)$ of the specimens was calculated based on Mander et al. ${ }^{30}$ The maximum axial load of Specimen A40-S100 was $8.3 \%$ higher than the maximum axial load of Specimen A30-S100. Also, Specimen A40-S100 achieved 5.6\% higher ductility compared to Specimen A30-S100. This may be because the force contribution of A40 SEA in Specimen A40-S100 was about 64\% greater than the force contribution of A30 SEA sections in Specimen A30-S100.

\section{Behavior of Column Specimens with 200 mm Tie Spacing}

252 Specimens B-S200, A30-S200, and A40-S200 were reinforced longitudinally with N12 bars, A30 253 SEA sections, and A40 SEA sections, respectively. The spacing of lateral ties for Specimens B-S200, A30-S200, and A40-S200 was $200 \mathrm{~mm}$ (7.87 in.) at centers. All these specimens were tested up to about $20 \%$ of the maximum axial load in the post-peak descending branch of the axial load-axial deformation response. The test results of Specimens B-S200, A30-S200 and A40-S200 are reported 
in Table 3. For Specimen B-S200, the first hairline crack began at about 93\% of the maximum axial load. This first crack occurred at the top one-third height of the specimens and then the cracks appeared at the midheight of the specimen. As the axial load increased close to the failure condition, the number and size of the cracks increased until spalling of the concrete cover was observed. Whereas, the first hairline cracks in Specimens A30-S200 and A40-S200 started at about 91\% and $87 \%$, respectively, of the corresponding maximum axial loads. These cracks were observed at the mid-height of the specimens. Afterwards, with the increase of the applied axial load, the number and size of the cracks increased and the concrete cover spalled off. The observed failure in Specimens BS200 was attributed to the crushing of the concrete core due to the spalling of concrete cover and the instability of longitudinal reinforcements (Fig. 6). The failure of Specimens A30-S200 and A40S200 was attributed to the spalling of the concrete cover, which was followed by outward buckling of longitudinal SEA sections (Fig. 6).

The axial load-axial deformation responses of the specimens with $200 \mathrm{~mm}$ tie spacing are shown in Fig. 5(c). The maximum axial load of Specimen A30-S200 was 2.9\% higher than the maximum axial load of Specimen B-S200. It is noted that the average yield tensile strength of steel bars was $49 \%$ higher than the average yield tensile strength of A30 SEA sections which resulted in $27 \%$ higher force contribution of $\mathrm{N} 12$ steel bars in B-S200 specimen compared to the force contribution of A30 SEA section in A30-S200 specimen at the maximum axial load. This increase in the maximum axial load in Specimen A30-S200 was because when the spacing of lateral ties increased, the failure of longitudinal reinforcement (steel bars or SEA sections) tended to be controlled by the buckling more than the yielding of longitudinal reinforcement. The confinement provided by the lateral ties decreased with the increase in the spacing of lateral ties. The maximum axial load of Specimen A30S200 was higher because A30 SEA section had a higher second moment of area and hence showed higher buckling load. In addition, Specimen A30-S200 obtained 6.7\% greater ductility compared to Specimen B-S200. The reason of greater ductility in Specimen A30-S200 was that as the buckling load of longitudinal reinforcement increased, the confinement effect to the concrete core increased. ${ }^{31}$ 
283

The maximum axial load of Specimen A40-S200 was $16.3 \%$ greater than the maximum axial load of Specimen B-S200. The reason of higher maximum axial load might be because the N12 steel bars in Specimen B-S200 buckled before yielding, whereas the A40 SEA sections yielded before buckling due to higher buckling load of A40 SEA sections than the buckling load of N12 steel bars. Also, Specimen A40-S200 showed 13.3\% higher ductility than Specimen B-S200. Hence, reinforcing specimens with SEA sections improved the performance of the specimens because of higher buckling load of SEA sections than the buckling load of steel bars and also because of the increase in the effective confinement of concrete core. The higher buckling load for SEA sections was because the second moment of area of the SEA section was greater than the second moment of area of the steel bar for the similar cross-sectional area. Specimen A40-S200 showed only 13.0\% higher maximum axial load compared to Specimen A30-S200. The higher maximum axial load in Specimen A40-S200 may be because A40 SEA sections in Specimens A40-S200 had higher force contribution than A30 SEA sections in Specimen A30-S200. Also, the ductility of Specimen A40-S200 was $6.2 \%$ higher than the ductility of Specimen A30-S200. The higher ductility in Specimen A40-S200 indicated that A40 SEA sections provided better confinement of the concrete core.

\section{Behavior of Column Specimens with $400 \mathrm{~mm}$ Tie Spacing}

Specimens B-S400, A30-S400, and A40-S400 were reinforced longitudinally with N12 steel bars, A30 SEA sections, and A40SEA sections, respectively. The spacing of lateral ties for B-S400, A30S400, and A40-S400 was 400 mm (15.74 in.) at centers. The test results of Specimens B-S400, A30S400 and A40-S400 are presented in Table 3. It is noted that the spacing of lateral ties in the specimen B-S400 was higher than the required spacing of lateral ties recommended in AS 3600-09 ${ }^{32}$ and ACI 318-14. ${ }^{33}$ Specimen B-S400 was designed to compare the behavior of Specimens A30-S400 and A40-S400 in terms of failure mode, strength, and ductility. The first hairline cracks in Specimens B-S400, A30-S400 and A40-S400 started at approximately 90\%, 89\%, and 88\%, respectively, of their maximum axial loads. These cracks were observed at the mid-height of the specimens. As the applied axial load increased close to the maximum axial load, the cracks extended both upwards and 
downwards of the specimens. Afterwards, the number and size of the cracks increased and the concrete cover spalled off. The failure in Specimen B-S400 was characterized by the crushing of concrete core, which occurred after the spalling of the concrete cover and outward buckling of longitudinal steel bars (Fig. 6). The failure in Specimens A30-S400 and A40-S400 was characterized by outward buckling of longitudinal SEA sections without crushing of concrete core (Fig. 6).

The axial load-axial deformation responses of the specimens with $400 \mathrm{~mm}$ tie spacing are shown in Fig. 5(d). The maximum axial load of Specimens A30-S400 was 42.5\% higher than the maximum axial load of Specimen B-S400. This may be because the use of SEA sections instead of steel bars in reinforcing square HSC column specimens significantly increased the buckling load of longitudinal reinforcement. The minimum second moment of area of the A30 SEA section was about $77 \%$ higher than the second moment of the area of the conventional steel bar for the same crosssectional area. In addition, the minimum radius of gyration of the A30 SEA section was about 50\% greater than the radius of gyration of the conventional steel bar for the same cross-sectional area.

The lower axial load carrying capacity of Specimen B-S400 was due to the instability of longitudinal bars (buckling of longitudinal steel bars at an early stage of loading), which pushed out the concrete cover and created weakness planes between the concrete cover and the concrete core. Similar observations were also reported Saatcioglu and Razvi. ${ }^{34}$ Therefore, the ductility of Specimen B-S400 was not further analysed. The maximum axial load of Specimen A40-S400 was 52.2\% higher than the maximum axial load of Specimen B-S400. This significantly high maximum axial load in Specimen A40-S400 was because the confinement efficiency of the concrete core of the specimens increased by using A40 SEA sections as longitudinal reinforcement instead of N12 steel bars. Another possible reason is that at maximum axial load, the conventional steel bars in Specimen BS400 reached buckling before yielding of the longitudinal steel bars. However, at maximum axial load, the A40 SEA sections in Specimen A40-S400 yielded before buckling as A40 SEA sections had much higher buckling load than N12 steel bars. The maximum axial load of Specimen A40-S400 was $6.9 \%$ higher than the maximum axial load of Specimen A30-S400. Also, the ductility of 
Specimen A40-S400 was 6.7\% higher than the ductility of Specimen A30-S400. This indicates that A40 SEA sections were more effective than A30 SEA sections in confining the concrete core of the specimen.

\section{INFLUENCE OF LATERAL TIE SPACING ON THE BEHAVIOR OF THE TESTED}

\section{SPECIMENS}

In this section, the influence of increasing the spacing of lateral ties from $50 \mathrm{~mm}$ (1.96 in.) to 400 $\mathrm{mm}$ (15.74 in.) in each group of specimens was investigated and discussed. The main aim is to investigate the effect of increasing lateral tie spacing on the strength, ductility and buckling load for each group of specimens. As discussed above, the use of SEA section as longitudinal reinforcement led to increased effective confinement of the concrete core and greater buckling load compared to the use of the N12 steel bars. Therefore, the improvements in the effective confinement of concrete core and buckling load for SEA sections influenced the strength and ductility of the specimens particularly with the increase in the lateral tie spacing. To be on the safe side, the minimum second moment of area and the minimum radius of gyration of the A30 and A40 SEA sections were selected to compare with the second moment of area and radius of gyration of N12 steel bars. The second moment of area and radius of gyration of N12 steel bar were about $1018 \mathrm{~mm}^{4}\left(0.0024 \mathrm{in}^{4}\right)$ and $3 \mathrm{~mm}$ (0.11 in.), respectively. The minimum second moment of area and the minimum radius of gyration of A30 SEA section were about $4380 \mathrm{~mm}^{4}\left(0.0105 \mathrm{in}^{4}\right)$ and $6 \mathrm{~mm}(0.23 \mathrm{in}$.). The minimum second moment of area and minimum radius of gyration of A40 SEA section were about $15700 \mathrm{~mm}^{4}(0.0377$ $\left.\mathrm{in}^{4}\right)$ and $8 \mathrm{~mm}(0.31 \mathrm{in}$.$) , respectively.$

The test results of the specimens in Group B are reported in Table 3. The axial load-axial deformation responses of the specimens in Group B are presented in Fig. 7(a). The maximum axial load of Specimen B-S50 was 11.5\% higher than the maximum axial load of Specimen B-S100. The ductility of Specimen B-S50 was $12.5 \%$ greater than the ductility of Specimen B-S100. Specimen B-S50 achieved $22.1 \%$ and $20.0 \%$ higher maximum axial load and ductility, respectively, compared to 
Specimen B-S200. Furthermore, the maximum axial load of Specimen B-S50 was 70.6\% higher than the maximum axial load of Specimen B-S400. The sharp decrease of the axial load of Specimen BS400 indicates that the buckling load of longitudinal steel bars and the confinement of the concrete core significantly decreased as the spacing of lateral ties increased from $50 \mathrm{~mm}$ (1.96 in.) to $400 \mathrm{~mm}$ (15.74 in.). Also, the ductility of the specimen with $400 \mathrm{~mm}$ (15.74 in.) tie spacing, which exceeds the required spacing of lateral ties by ACI $318-14,{ }^{33}$ was not calculated as the specimen failed prematurely. The premature failure of Specimen B-S400 was because the large lateral tie spacing of Specimen B-S400 resulted in buckling of the longitudinal reinforcement at an early stage of loading. The test results of the specimens in Group A30 are reported in Table 3. The axial load-axial deformation responses of the specimens in Group A30 are presented in Fig. 7(b). Compared to Specimen A30-S100, the maximum axial load of Specimen A30-S50 was only $0.2 \%$ higher. This may be because the formation of a natural separation plane between the cover and the concrete core caused the failure of concrete cover in Specimen A30-S50 due to the closely spaced lateral ties. However, Specimen A30-S50 achieved 44.4\% higher ductility than Specimen A30-S100. Specimen A30-S50 obtained $6.3 \%$ higher maximum axial load than Specimen A30-S200. In addition, the ductility of Specimen A30-S50 was 62.5\% higher than the ductility of Specimen A30-S200. Specimen A30-S50 achieved 7.3\% and 73.3\% higher maximum axial load and ductility, respectively, than Specimen A30-S400. It is noted that the lateral tie spacing of Specimen A30-S50 was $50 \mathrm{~mm}$ (1.96 in.) and lateral tie spacing of Specimen A30-S400 was 400 mm (15.74 in.).

The test results of the specimens in Group A40 are reported in Table 3. The axial load-axial deformation responses of the specimens in Group A40 are presented in Fig. 7(c). The maximum axial load of Specimen A40-S50 was 6.1\% greater than the maximum axial load of Specimen A40-S100. Moreover, the ductility of Specimen A40-S50 was 42.1\% higher than the ductility of Specimen A40S100. Specimen A40-S50 obtained 7.8\% and 58.8\% higher maximum axial load and ductility, respectively, compared to Specimen A40-S200. Also, Specimen A40-S50 obtained about 15.1\% and 
the increase of the spacing of lateral ties from $50 \mathrm{~mm}$ (1.96 in.) to $400 \mathrm{~mm}$ (15.74 in.), the maximum axial load and ductility of the specimens reinforced with A40 SEA sections decreased by about $15.1 \%$ and $68.8 \%$, respectively. These decreases in the strength and ductility of specimens reinforced with A40 SEA were because the confinement of the concrete core decreased due to the increased spacing of lateral tie up to $400 \mathrm{~mm}$ (15.74 in.). Under axial compression, the effect of lateral ties to restrain the expansion of concrete core decreases as the spacing of lateral ties increases, which results in decreasing the strength and ductility of the column, similar to specimens reinforced with conventional steel bars.

\section{EVALUATION OF CONCENTRIC AXIAL LOAD CAPACITY}

The axial load capacity $\left(P_{n}\right)$ for each column specimen was calculated using AS 3600-09 32 (Eq. (2)). It is noted that the recommendation in AS $3600-09^{32}$ is only applicable for conventional steel bar reinforced concrete. In this study, Eq. (2) was used to calculate the axial load capacity for column specimens reinforced longitudinally with SEA sections to investigate whether AS $3600-09^{32}$ based recommendations for steel bar reinforced concrete columns can be applied for the SEA reinforced concrete columns.

$$
P_{n}=\alpha_{1} f_{c}^{\prime}\left(A_{g}-A_{s}\right)+f_{y} A_{s}
$$

where, $A_{g}$ is the gross cross-sectional area of concrete column specimen, $A_{s}$ is the total area of longitudinal reinforcement, $f_{c}^{\prime}$ is the concrete compressive strength and $f_{y}$ is the yield tensile strength of longitudinal reinforcement. The $\alpha_{1}$ is a reduction factor that takes into account the differences in shape, concrete casting practice and size between standard concrete cylinders and concrete columns. ${ }^{35}$ In this study, the reduction factor is calculated according to AS $3600-09^{32}$ as a function of the compressive strength of concrete $\left(\alpha_{1}=1-0.003 f_{c}^{\prime}\right.$ within the limit $\left.0.72 \leq \alpha_{1} \leq 0.85\right)$

The experimental and calculated maximum axial loads of the tested column specimens are presented in Table 4. In Table 4, $P_{\max }$ indicates the maximum axial load obtained from the experimental 
411 investigations, $P_{n}$ indicates the calculated axial load capacity using Eq. (2), and $P_{\max } / P_{n}$ indicates

412 the ratio of the experimental to the calculated maximum axial load. It is noted that the spacing of 413 lateral ties in Specimen B-S400 was much higher than the required spacing of lateral ties by ACI $414 \quad 318-14 .^{33}$

415 It can be observed from Table 4 that the $P_{\max } / P_{n}$ ratios are either higher than or equal to 1.0 when 416 the lateral tie spacing is $50 \mathrm{~mm}$ (1.96 in.) and $100 \mathrm{~mm}$ (3.93 in.) for specimens reinforced with N12 steel bars and SEA sections. For the lateral tie spacing of $200 \mathrm{~mm}$ (7.87 in.) and $400 \mathrm{~mm}$ (15.74 in.), the $P_{\max } / P_{n}$ ratios are 0.91 and 0.65 , respectively, for specimens reinforced with N12 steel bars. The rapid decrease of the $P_{\max } / P_{n}$ ratio for specimens reinforced with N12 steel bar indicates the loss of confinement effectiveness of the concrete core and the loss of buckling load of the steel bars for larger spacing of lateral ties. However, for the lateral tie spacing of $200 \mathrm{~mm}$ (7.87 in.) and $400 \mathrm{~mm}$ SEA sections. Also, for the lateral tie spacing of $200 \mathrm{~mm}$ (7.87 in.) and $400 \mathrm{~mm}$ (15.74 in.), the $P_{\text {max }} / P_{n}$ ratios are 0.98 and 0.92 , respectively, for specimens reinforced with A40 SEA sections.

The higher $P_{\max } / P_{n}$ ratios for specimens reinforced with SEA sections, especially for spacing of larger ties (200 mm (7.87 in.) and $400 \mathrm{~mm}(15.74 \mathrm{in})$.$) , indicates the better performance of the$ specimens reinforced with A30 and A40 SEA sections compared to the specimens reinforced with N12 steel bars. Hence, larger lateral tie spacing might be recommended for specimens reinforced with A30 and A40 SEA sections.

\section{CONCLUSIONS}

Twelve square HSC column specimens were tested under concentric axial loads. Eight of the specimens were reinforced longitudinally with SEA sections (A30 and A40) to investigate the effect of the SEA sections as longitudinal reinforcement with different spacing of lateral ties. For comparison purposes, four specimens were reinforced longitudinally with conventional steel bars (N12 steel bars). Based on the test results of this study, the following conclusions are drawn: 
437 1. In general, the failure of the specimens reinforced with N12 steel bars was characterised by the 438 buckling of longitudinal bars, which was followed by the fracture of lateral ties at welded points for $43950 \mathrm{~mm}(1.96$ in.) and $100 \mathrm{~mm}$ (3.93 in.) center-to-center spacing of lateral ties. However, for 200 $\mathrm{mm}$ (7.87 in.) and $400 \mathrm{~mm}$ (15.74 in.) center-to-center spacing of lateral ties, the failure of the specimen was characterised by buckling of longitudinal steel bars and the crushing of concrete core.

442 The failure of specimens reinforced with A30 and A40 SEA sections was characterized by the 443 buckling of longitudinal SEA sections, which was followed by the fracture of lateral ties at welded points for $50 \mathrm{~mm}$ (1.96 in.) center-to-center spacing of lateral ties. Whereas, in general, the failure of specimens reinforced with A30 and A40 SEA sections with center-to-center spacing of lateral ties of $100 \mathrm{~mm}$ (3.93 in.) to $400 \mathrm{~mm}$ (15.74 in.) was attributed to the buckling of longitudinal SEA sections and then cracking of the concrete core.

2. The maximum axial loads of Specimens B-S50 and B-S100 were $11.6 \%$ and $2.7 \%$, respectively, greater than the maximum axial loads of Specimens A30-S50 and A30-S100. However, at the maximum axial load, the force contribution of N12 steel bars in Specimen B-S50 and B-S100 was 27\% higher than the force contribution of A30 SEA sections in Specimens A30-S50 and A30-S100, respectively. The maximum axial loads of Specimens B-S200 and B-S400 were $2.5 \%$ and 52\%, respectively, lower than the maximum axial loads of Specimens A30-S200 and A30-S400. At the same lateral tie spacing, all specimens reinforced with A30 SEA sections exhibited higher ductility compared to reference specimens reinforced with N12 steel bars. This was because the use of the A30 SEA sections as longitudinal reinforcement in HSC column specimens increased the effective confinement of the concrete core of the specimens.

3. For the same center-to-center spacing of lateral ties, all specimens reinforced longitudinally with A40 SEA sections exhibited higher maximum axial load and ductility than the corresponding specimens reinforced longitudinally with N12 steel bars. Increasing the spacing of lateral ties from $50 \mathrm{~mm}$ (1.96 in.) to $400 \mathrm{~mm}$ (15.74 in.) led to a decrease of $15.1 \%$ of the maximum axial load for specimens reinforced with A40 SEA sections. In addition, Specimens A40-S50, A40-S100, and A40- 
463 S200 showed higher maximum axial load and ductility compared to the Specimens A30-S50, A30-

464 S100 and A30-S200, respectively. The reason for higher maximum axial load and ductility of 465 specimens reinforced with A40 SEA sections was due to the combined effect of the increased 466 confinement effectiveness of the concrete core and the greater cross section area of A40 SEA section

467 4. For the same center-to-center spacing of lateral ties, all specimens reinforced longitudinally with 468 A40 SEA sections exhibited higher maximum axial load and ductility than the corresponding 469 specimens reinforced longitudinally with N12 steel bars. Increasing the spacing of lateral ties from $50 \mathrm{~mm}$ (1.96 in.) to $400 \mathrm{~mm}$ (15.74 in.) led to a decrease of $15.1 \%$ of the maximum axial load for specimens reinforced with A40 SEA sections. In addition, Specimens A40-S50, A40-S100, and A40S200 showed higher maximum axial load and ductility compared to the Specimens A30-S50, A30S100 and A30-S200, respectively. The reason for higher maximum axial load and ductility of specimens reinforced with A40 SEA sections was due to the combined effect of the increased confinement effectiveness of the concrete core and the greater cross section area of A40 SEA section 5. For specimens with lateral tie spacing of $400 \mathrm{~mm}$ (15.74 in.), the use of the conventional steel bar as longitudinal reinforcement led to a premature failure of the specimen, while the use of the SEA sections as longitudinal reinforcement did not lead to premature failure of the specimen. This was because the buckling load of SEA sections was significantly higher than the buckling load of steel bars.

Finally, based on the test results of the HSC column specimens, it is evident that the use of SEA sections as longitudinal reinforcement for HSC columns can provide higher maximum axial load and ductility compared to the HSC columns reinforced longitudinally with conventional steel bars.

\section{ACKNOWLEDGMENTS}

The authors would like to thank the University of Wollongong, Australia and technical officers at the High Bay laboratory for their help in the experimental program of this study. Also, the first author thanks the support of the Iraqi Government for his full Ph.D. scholarship. 
490 1. Mirza, S. A., Hyttinen, V., and Hyttinen, E., "Physical Tests and Analyses of Composite Steel491 Concrete Beam-Columns," Journal of Structural Engineering, ASCE, V. 122, No. 11. 1996, pp. $1317-1326$

493

2. Ellobody, E., and Young, B., "Numerical Simulation of Concrete Encased Steel Composite

Columns," Journal of Constructional Steel Research, V. 67, No. 2. 2011, pp. 211-222.

3. Kim, C. S., Park, H. G., Chung, K. S., and Choi, I. R., "Eccentric Axial Load Testing for Concrete-

Encased Steel Columns Using $800 \mathrm{MPa}$ Steel and $100 \mathrm{MPa}$ Concrete," Journal of Structural Engineering, ASCE, V. 138, No. 8. 2012, pp. 1019-1031.

4. Hunaiti, Y., Fattah, B. A., and Fattah, A., "Design Considerations of Partially Encased Composite Columns," Proceedings of the ICE-Structures and Buildings, V. 104, No. 1. 1994, pp. 75-82.

5. Leite, L., Bonet, J., Pallarés, L., Miguel, P. F., and Fernández-Prada, M. A., "Experimental 501 Research on High Strength Concrete Slender Columns Subjected to Compression and Uniaxial Bending with Unequal Eccentricities at the Ends," Engineering Structures, V. 48, 2013, pp. 220-232.

6. Campione, G., Monaco, A., and Minafò, G., "Shear Strength of High-Strength Concrete Beams: Modeling and Design Recommendations," Engineering Structures, V. 69, 2014, pp. 116-122.

7. Hadi, M. N. S., Balanji, E. K., and Sheikh, M. N., "Behavior of Steel Fiber-Reinforced HighStrength Concrete Columns under Different Loads," ACI Structural Journal, V. 114, No. 04. 2017, pp. 815-826.

8. Sheikh, S. A., Shah, D. V., and Khoury, S. S., "Confinement of High-Strength Concrete Columns," ACI Structural Journal, V. 91, No. 1. 1994, pp. 100-111.

510 9. El-Tawil, S., and Deierlein, G. G., "Strength and Ductility of Concrete Encased Composite 511 Columns," Journal of Structural Engineering, V. 125, No. 9. 1999, pp. 1009-1019.

512 10. Li, B., and Park, R., "Confining Reinforcement for High Strength Concrete Columns," ACI 513 Structural Journal, V. 101, No. 3. 2004, pp. 314-324. 
11. Ho, J., Lam, J., and Kwan, A., "Effectiveness of Adding Confinement for Ductility Improvement of High-Strength Concrete Columns," Engineering Structures, V. 32, No. 3. 2010, pp. 714-725.

12. Awati, M., and Khadiranaikar, R., "Behavior of Concentrically Loaded High Performance Concrete Tied Columns," Engineering Structures, V. 37, . 2012, pp. 76-87.

13. Woods, J. M., Kiousis, P. D., Ehsani, M. R., Saadatmanesh H., and Fritz W., "Bending Ductility of Rectangular High Strength Concrete Columns," Engineering structures, V. 29, No. 8. 2007, pp. 1783-1790.

14. Samani, A. K., Attard, M. M., and Foster, S. J., "Ductility in Concentrically Loaded Reinforced Concrete Columns," Australian Journal of Structural Engineering, V. 16, No. 3. 2015, pp. 237-250. 15. Yang, K. H., and Kim, W. W., "Axial Compression Performance of Reinforced Concrete Short Columns with Supplementary V-Shaped Ties," ACI Structural Journal, V. 113, No. 6. 2016, pp. 1347-1356.

16. Razvi, S. R., and Saatcioglu, M., "Strength and Deformability of Confined High-Strength Concrete Columns," ACI Structural Journal, V. 91, No. 6. 1994, pp. 678-687.

17. Shin, H. O., Yoon, Y. S., Cook, W. D., and Mitchell, D., "Enhancing the Confinement of UltraHigh-Strength Concrete Columns Using Headed Crossties," Engineering structures, V. 127, 2016, pp. 86-100.

18. Foster, S. J., "Design and Detailing of High Strength Concrete Columns," UNICIV Report No. R-375, University of New South Wales, Sydney, Australia, 1999.

19. Popovic, D., Hancock, G. J., and Rasmussen, K. J. R. (1999). "Axial compression tests of coldformed angles." Journal of Structural Engineering. V. 125, No. 5, pp. 515-523.

20. Young, B. (2004). "Tests and design of fixed-ended cold-formed steel plain angle columns." Journal of structural engineering. V. 130, No. 12, pp. 1931-1940.

21. Ellobody, E., and Young, B. (2005). "Behavior of cold-formed steel plain angle columns." Journal of structural engineering. V. 131, No. 3, pp. 457-466. 
22. AS 1012.3.1-14, "Methods of testing concrete-Method 3.1: determination of properties related to the consistency of concrete-Slump test." Standards Australia, Sydney, Australia, 2014.

23. AS 1012.9-99, "Methods of Testing Concrete, Determination of the Compressive Strength of Concrete Specimens," Standard Australia, Sydney, Australia, 1999

24. AS 1391-07,"Metallic Materials-Tensile Testing at Ambient Temperature,” Standards Australia, Sydney, Australia, 2007.

25. OneSteel, "Know Your Steel: Steel Reference Guide,", 2010, [www.onesteel.com].

26. Hadi, M. N. S., and Youssef, J., "Experimental Investigation of GFRP-Reinforced and GFRPEncased Square Concrete Specimens under Axial and Eccentric Load, and Four-Point Bending Test," Journal of Composites for Construction, ASCE, V. 93, 2016, pp. 1-16.

27. Hadi, M. N. S., Khan, Q. S., and Sheikh, M. N., "Axial and Flexural Behavior of Unreinforced and FRP Bar Reinforced Circular Concrete Filled FRP Tube Columns," Construction and Building Materials, V. 122, 2016, pp. 43-53.

28. Pessiki, S., and Pieroni, A., "Axial Load Behavior of Large-Scale Spirally-Reinforced HighStrength Concrete Columns," ACI Structural Journal, V. 94, No. 3. May-June 1997, pp. 304-313. 29. Sheikh, M. N., and Legeron, F., "Performance Based Seismic Assessment of Bridges Designed According to Canadian Highway Bridge Design Code," Canadian Journal of Civil Engineering, V. 41, No. 9. 2014, pp. 777-787.

30. Mander, J. B., Priestley, M. J., and Park, R. (1988). "Theoretical stress-strain model for confined concrete." Journal of Structural Engineering. V. 114, No. 8, 1988, pp. 1804-1826.

31. Campione, G., and Minafò, G., "Compressive Behavior of Short High-Strength Concrete Columns," Engineering Structures, V. 32, No. 9. 2010, pp. 2755-2766.

32. AS 3600-09, “Concrete Structures,” Standards Australia, Sydney, Australia, 2009.

33. ACI Committee 318, "Building Code Requirements for Structural Concrete (ACI 318-14) and Commentary,” American Concrete Institute, Farmington Hills, MI, 2014, 148 pp. 
564 34. Saatcioglu, M., and Razvi, S. R., "High-Strength Concrete Columns with Square Sections under

565 Concentric Compression," Journal of Structural Engineering, ASCE, V. 124, No. 12. 1998, pp. $566 \quad 1438-1447$.

567 35. Ozbakkaloglu, T., and Saatcioglu, M., "Rectangular Stress Block for High-Strength Concrete," 568 ACI Structural Journal, V. 101, No. 4. 2004, pp. 475-483.

569

570

571

572

573

574

575

576

577

578

579

580

581

582

583

584

585

586

587

588

589

590

8

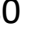

81

83

84

86

- n

\section{TABLES AND FIGURES}

\section{List of Tables:}

Table 1 - Test matrix

Table 2 - Tensile properties of steel equal angle (SEA) sections

Table 3 - Summary of the test results of column specimens

Table 4 - Experimental and analytical concentric axial load capacity of column specimens

(1)

82

5

(5) 


\section{List of Figures:}

599 Fig. 1 - Geometry and reinforcement details of the column specimens. (Note: $1 \mathrm{~mm}=0.0393 \mathrm{in}$.)

600 Fig. 2 - Steel cage with SEA sections. (Note: $1 \mathrm{~mm}=0.0393 \mathrm{in.}$ )

601 Fig. 3 - Test setup.

602 Fig. 4 - Tested specimens after failure: (a) Group B Specimens, (b) Group A30 specimens; and (c) 603 Group A40 specimens.

604 Fig. 5 - Axial load-axial deformation response of column specimens with tie spacing: (a) $50 \mathrm{~mm}$; 605 (b) $100 \mathrm{~mm}$; (c) $200 \mathrm{~mm}$; and (d) $400 \mathrm{~mm}$. (Note: $1 \mathrm{kN}=0.2248 \mathrm{kip} ; 1 \mathrm{~mm}=0.0393 \mathrm{in}$.) 606 Fig. 6-Close-up views of the failure modes of column specimens (a) B-S200; (b) B-S400; (c) A30607 S200; (d) A30-S400; (e) A40-S200; and (f) A40-S400.

608 Fig. 7 - Axial load-axial deformation response: (a) Group B specimens; (b) Group A30 specimens; 609 and (c) Group A40 specimens. (Note: $1 \mathrm{kN}=0.2248 \mathrm{kip} ; 1 \mathrm{~mm}=0.0393 \mathrm{in}$.) 
Table 1-Test matrix

\begin{tabular}{|c|c|c|c|c|c|c|c|c|c|}
\hline \multirow{3}{*}{ Group } & \multirow{3}{*}{$\begin{array}{l}\text { Specimen } \\
\text { Labels }\end{array}$} & \multicolumn{6}{|c|}{ Longitudinal Reinforcement } & \multirow{2}{*}{\multicolumn{2}{|c|}{ Lateral Reinforcement }} \\
\hline & & \multirow[b]{2}{*}{$\begin{array}{l}\text { Reinforcement } \\
\text { Type }\end{array}$} & \multirow[b]{2}{*}{ Number } & \multicolumn{2}{|l|}{ Bar } & \multicolumn{2}{|c|}{$\begin{array}{l}\text { Steel Equal Angle } \\
\text { (SEA) Section }\end{array}$} & & \\
\hline & & & & $\begin{array}{l}\text { Diameter } \\
\quad(\mathrm{mm})\end{array}$ & $\begin{array}{l}\rho_{b} \\
\%\end{array}$ & $\begin{array}{l}\text { Dimension } \\
\quad(\mathrm{mm})\end{array}$ & $\begin{array}{c}\rho_{S E A} \\
\%\end{array}$ & $\begin{array}{l}\text { Diameter } \\
(\mathrm{mm})\end{array}$ & $\begin{array}{l}\text { Spacing } \\
\text { (mm) }\end{array}$ \\
\hline \multirow{4}{*}{ B } & $\mathrm{B}-\mathrm{S} 50$ & \multirow{4}{*}{ Steel Bar } & \multirow{4}{*}{4} & \multirow{4}{*}{12} & \multirow{4}{*}{1.03} & \multirow{4}{*}{ - } & \multirow{4}{*}{-} & \multirow{4}{*}{10} & 50 \\
\hline & B-S100 & & & & & & & & 100 \\
\hline & B-S200 & & & & & & & & 200 \\
\hline & B-S400 & & & & & & & & 400 \\
\hline \multirow{4}{*}{$\mathrm{A} 30$} & $\mathrm{~A} 30-\mathrm{S} 50$ & \multirow{4}{*}{$\begin{array}{c}\text { Steel Equal } \\
\text { Angle (SEA) } \\
\text { Section }\end{array}$} & \multirow{4}{*}{4} & \multirow{4}{*}{\multicolumn{2}{|c|}{-}} & \multirow{4}{*}{$\begin{array}{c}29.1 \times \\
2.25\end{array}$} & \multirow{4}{*}{1.11} & \multirow{4}{*}{10} & 50 \\
\hline & A30-S100 & & & & & & & & 100 \\
\hline & A30-S200 & & & & & & & & 200 \\
\hline & A30-S400 & & & & & & & & 400 \\
\hline \multirow{4}{*}{ A40 } & A40-S50 & \multirow{4}{*}{$\begin{array}{c}\text { Steel Equal } \\
\text { Angle (SEA) } \\
\text { Section }\end{array}$} & \multirow{4}{*}{4} & \multirow{4}{*}{\multicolumn{2}{|c|}{-}} & \multirow{4}{*}{$39.3 \times 3.7$} & \multirow{4}{*}{2.43} & \multirow{4}{*}{10} & 50 \\
\hline & A40-S100 & & & & & & & & 100 \\
\hline & A40-S200 & & & & & & & & 200 \\
\hline & A40-S400 & & & & & & & & 400 \\
\hline
\end{tabular}

Notes: $1 \mathrm{~mm}=0.0393$ in.

$\rho_{b}$ Volumetric ratio of longitudinal reinforcement (steel bars) in specimen cross section.

$\rho_{S E A}$ Volumetric ratio of longitudinal reinforcement (steel equal angle sections) in specimen cross section. 
Table 2-Tensile properties of steel equal angle (SEA) sections

\begin{tabular}{c|c|c|c|c|c}
\hline $\begin{array}{c}\text { Steel Equal } \\
\text { Angle } \\
\text { (SEA)Section }\end{array}$ & $\begin{array}{c}\text { Leg } \\
\text { Width } \\
(\mathrm{mm})\end{array}$ & $\begin{array}{c}\text { Thickness } \\
(\mathrm{mm})\end{array}$ & $\begin{array}{c}\text { Area } \\
\left(\mathrm{mm}^{2}\right)\end{array}$ & $\begin{array}{c}\text { Yield } \\
\text { Tensile } \\
\text { Strength } \\
(\mathrm{MPa})\end{array}$ & $\begin{array}{c}\text { Modulus } \\
\text { of } \\
\text { Elasticity } \\
(\mathrm{GPa})\end{array}$ \\
\hline \multicolumn{6}{|c}{ Nominal } \\
\hline A30 & 30 & 2.5 & 132 & 350 & 200 \\
\hline A40 & 40 & 4 & 280 & 450 & 200 \\
\hline A30 & 29.1 & 2.25 & 122.6 & 374 & 208 \\
\hline A40 & 39.3 & 3.7 & 268.3 & 473 & 205 \\
\hline
\end{tabular}

Notes: $1 \mathrm{~mm}=0.0393$ in.; $1 \mathrm{MPa}=0.1450 \mathrm{ksi}$.

Table 3-Summary of the test results of column specimens

\begin{tabular}{c|c|c|c|c}
\hline Specimen & $\begin{array}{c}\text { Maximum } \\
\text { concentric axial } \\
\text { load, } P_{\max }(\mathrm{kN})\end{array}$ & $\begin{array}{c}\text { Axial } \\
\text { deformation } \\
\text { at } P_{\max } \\
(\mathrm{mm})\end{array}$ & $\begin{array}{c}\text { Ultimate Axial } \\
\text { Deformation } \\
\Delta_{u}{ }^{\mathrm{a}} \\
(\mathrm{mm})\end{array}$ & Ductility \\
\hline B-S50 & 2929 & 2.3 & 3.1 & 1.8 \\
\hline A30-S50 & 2625 & 2.2 & 4.0 & 2.6 \\
\hline A40-S50 & 3009 & 2.2 & 3.9 & 2.7 \\
\hline B-S100 & 2626 & 2.1 & 2.7 & 1.6 \\
\hline A30-S100 & 2619 & 2.3 & 2.8 & 1.8 \\
\hline A40-S100 & 2836 & 2.4 & 3.2 & 1.9 \\
\hline B-S200 & 2399 & 1.8 & 2.3 & 1.5 \\
\hline A30-S200 & 2469 & 1.9 & 2.4 & 1.6 \\
\hline A40-S200 & 2791 & 2.2 & 2.8 & - \\
\hline B-S400 & 1717 & 1.8 & - & 1.5 \\
\hline A30-S400 & 2446 & 2.1 & 2.4 & 1.6 \\
\hline A40-S400 & 2614 & 2.2 & 2.7 & \\
\hline N
\end{tabular}

Notes: $1 \mathrm{kN}=0.2248 \mathrm{kip} ; 1 \mathrm{~mm}=0.0393$ in.

${ }^{\text {a }}$ represents the deformation corresponding to $80 \%$ of the maximum axial load in the descending branch of the axial load-axial deformation behavior. 
Table 4 - Experimental and analytical concentric axial load capacity of column specimens

\begin{tabular}{|c|c|c|c|c|}
\hline \multirow[b]{2}{*}{ Group } & \multirow[b]{2}{*}{ Specimen } & \multicolumn{2}{|c|}{ Maximum concentric axial load $(\mathrm{kN})$} & \multirow[b]{2}{*}{$\frac{P_{\max }}{P_{n}}$} \\
\hline & & $\begin{array}{l}\text { Experimental } \\
\left(\mathrm{P}_{\max }\right)\end{array}$ & $\begin{array}{l}\text { Analytical } \\
\left(\mathrm{P}_{\mathrm{n}}\right)\end{array}$ & \\
\hline \multirow{4}{*}{ B } & B-S50 & 2929 & 2627 & 1.11 \\
\hline & B-S100 & 2626 & 2627 & 1.00 \\
\hline & B-S200 & 2399 & 2627 & 0.91 \\
\hline & B-S400 & 1718 & 2627 & 0.65 \\
\hline \multirow{4}{*}{ A30 } & A30-S50 & 2625 & 2557 & 1.03 \\
\hline & A30-S100 & 2619 & 2557 & 1.02 \\
\hline & A30-S200 & 2469 & 2557 & 0.97 \\
\hline & A30-S400 & 2446 & 2557 & 0.96 \\
\hline \multirow{4}{*}{$\mathrm{A} 40$} & A40-S50 & 3009 & 2849 & 1.06 \\
\hline & A40-S100 & 2836 & 2849 & 1.00 \\
\hline & $\mathrm{A} 40-\mathrm{S} 200$ & 2791 & 2849 & 0.98 \\
\hline & A $40-S 400$ & 2614 & 2849 & 0.92 \\
\hline
\end{tabular}

Note: $1 \mathrm{kN}=0.2248 \mathrm{kip}$ 


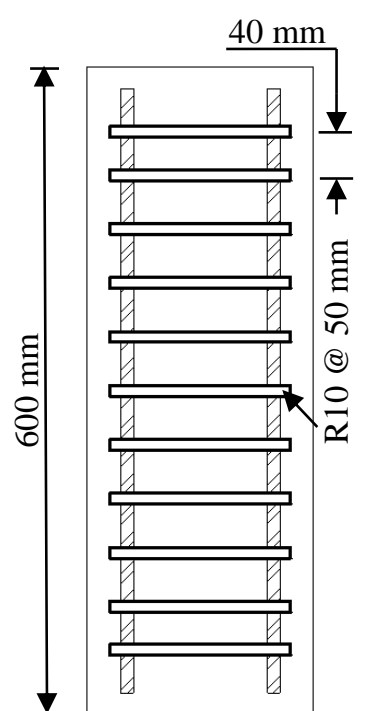

B-S50

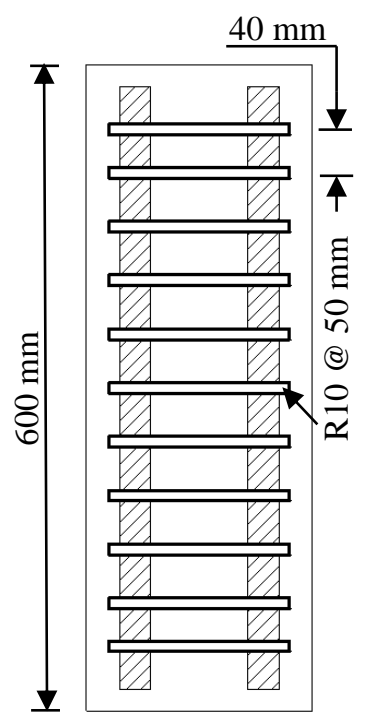

A30-S50

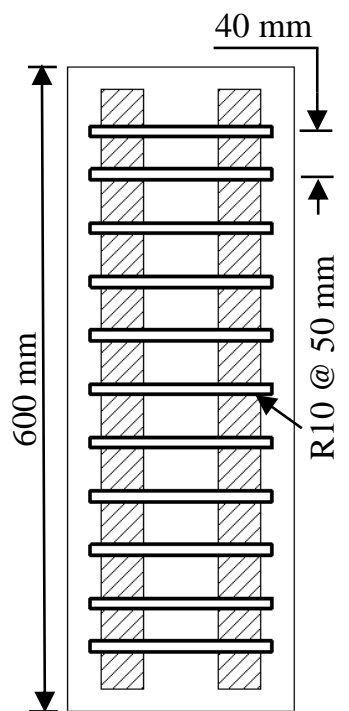

A40-S50

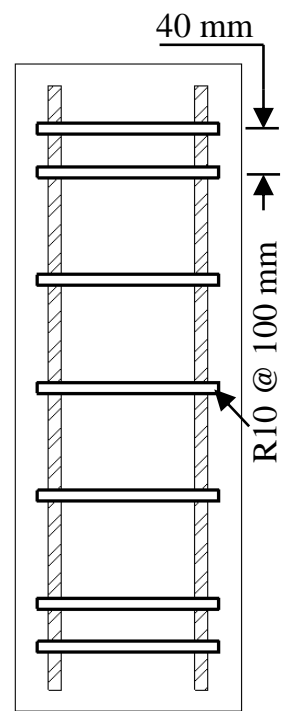

B-S100

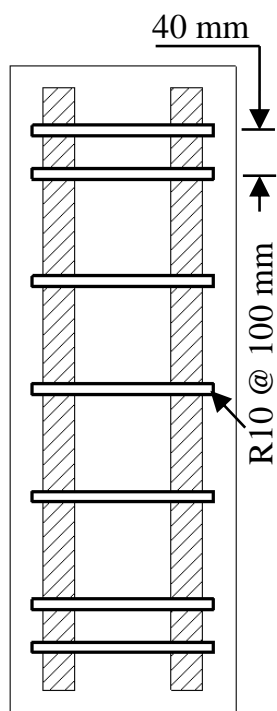

A30-S100

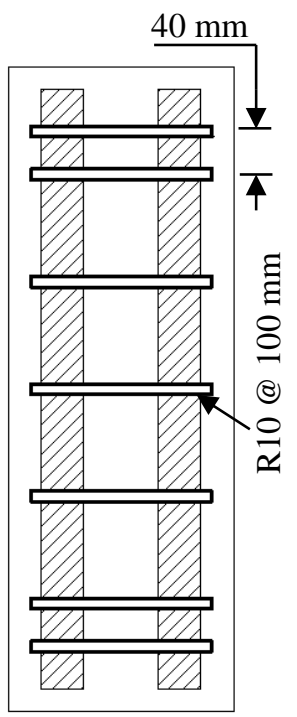

A40-S100

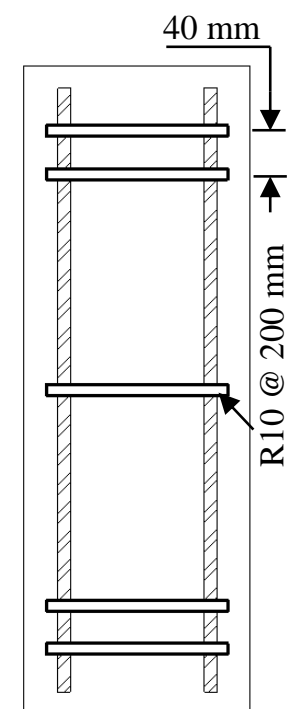

B-S200

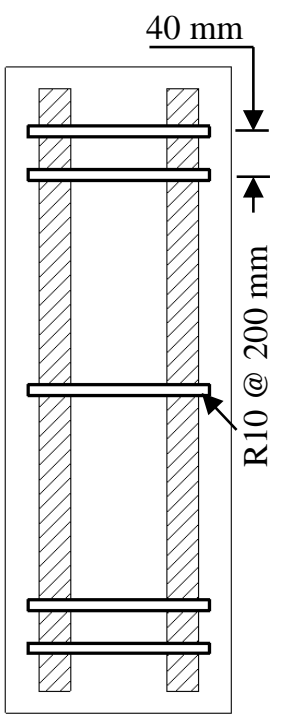

A30-S200

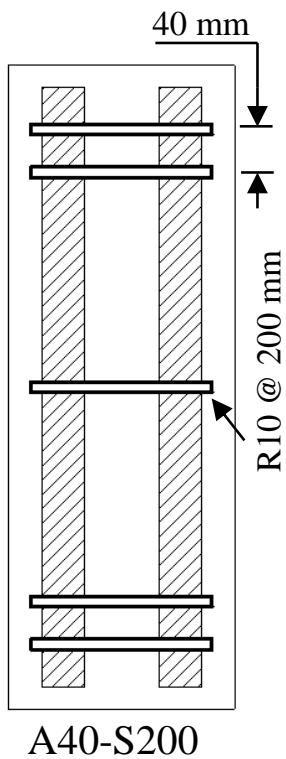

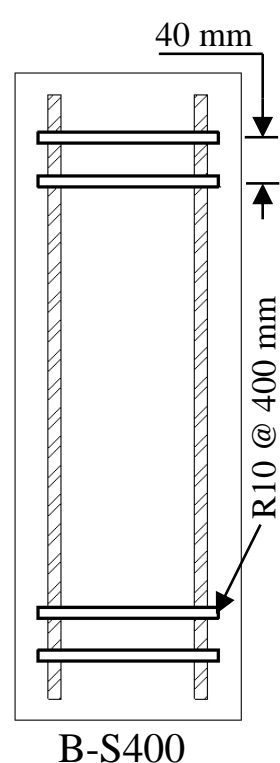

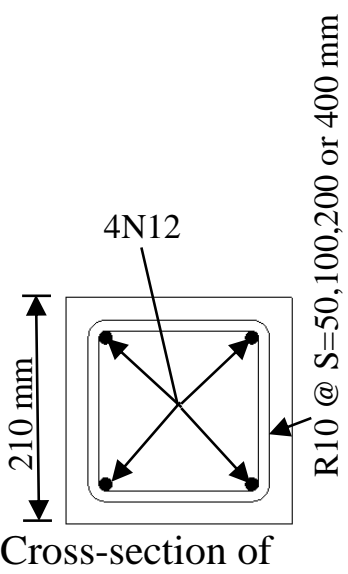

Group B specimens

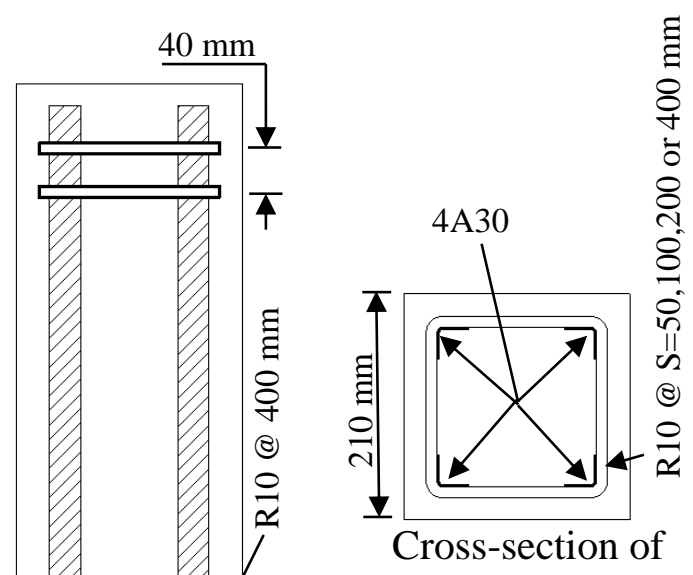

Group A30 specimens

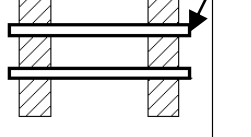

A30-S400

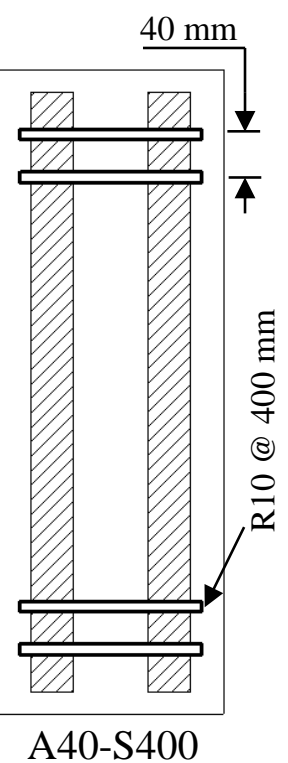

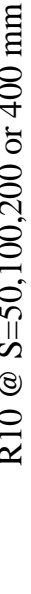

Cross-section of

Group A40 specimens

Fig. 1-Geometry and reinforcement details of the column specimens. (Note: $1 \mathrm{~mm}=0.0393$

in.) 


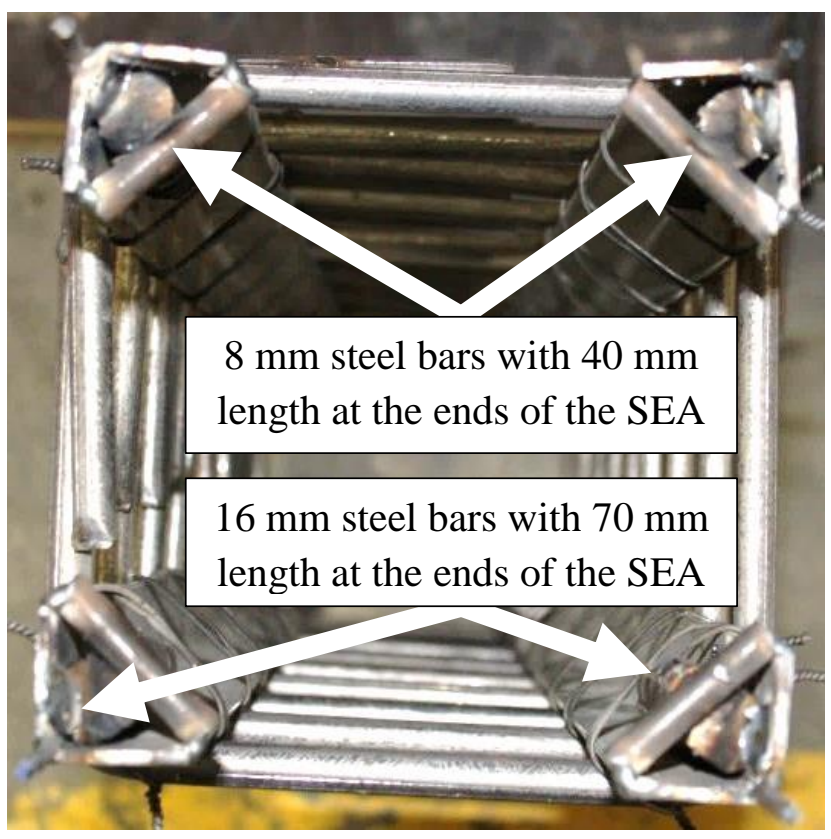

Fig. 2-Steel cage with SEA sections. (Note: $1 \mathrm{~mm}=0.0393 \mathrm{in.})$

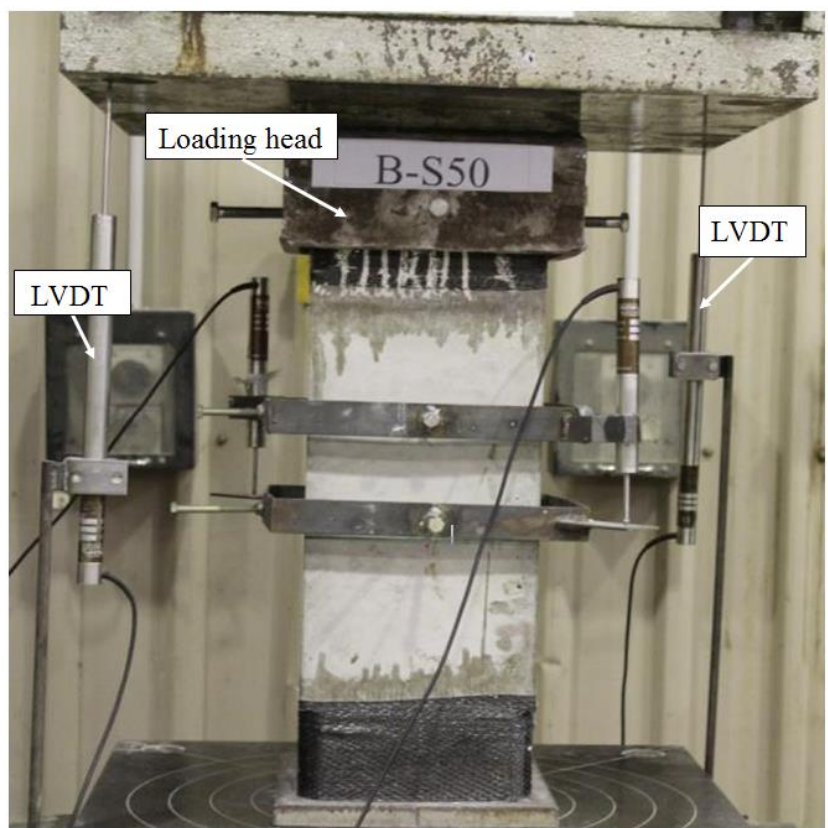

Fig. 3-Test setup. 

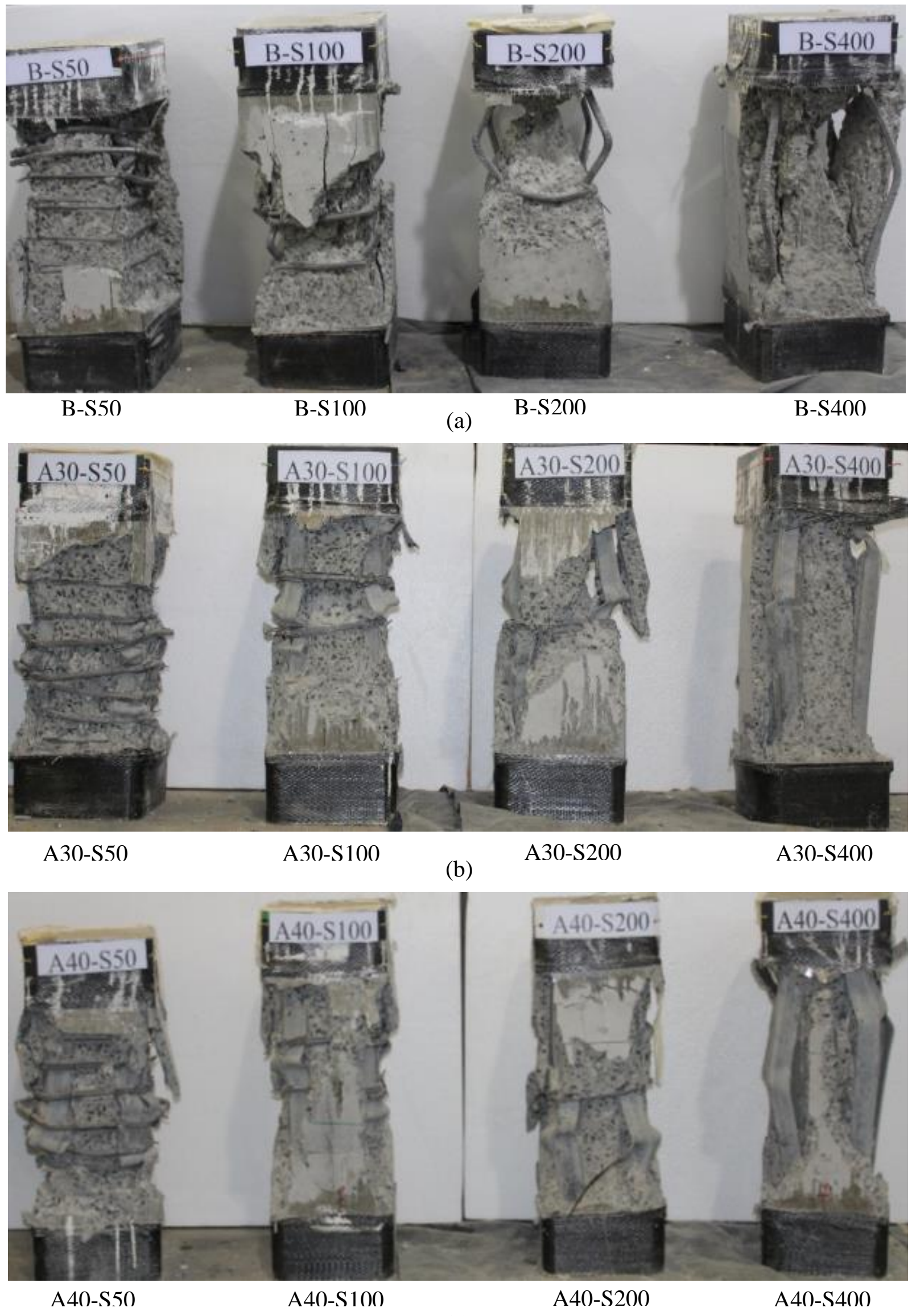

(c)

Fig. 4-Tested specimens after failure: (a) Group B Specimens, (b) Group A30 specimens; and (c) Group A40 specimens. 


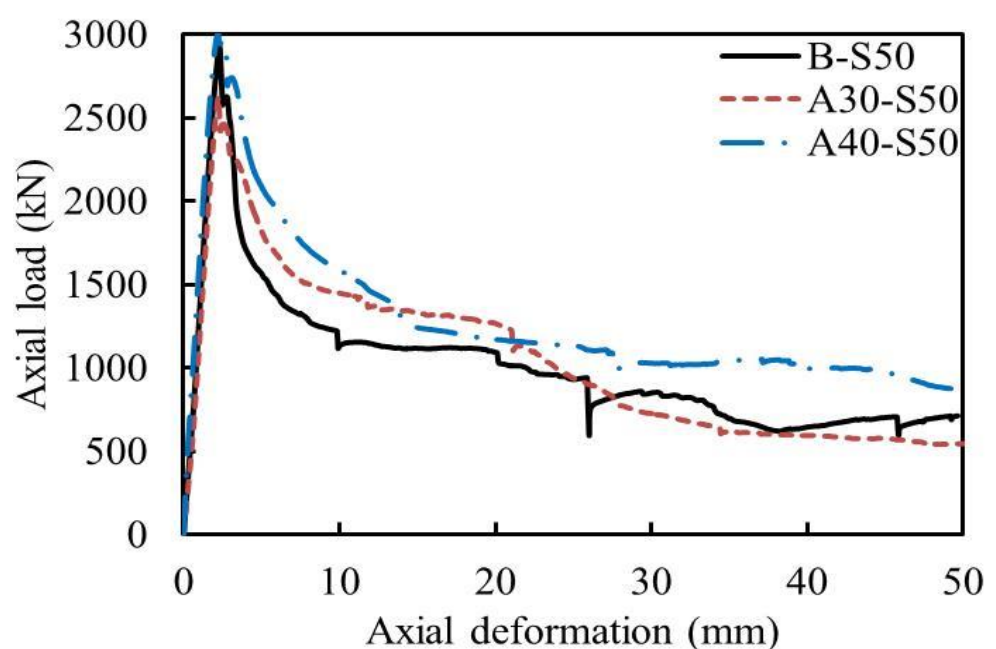

(a)

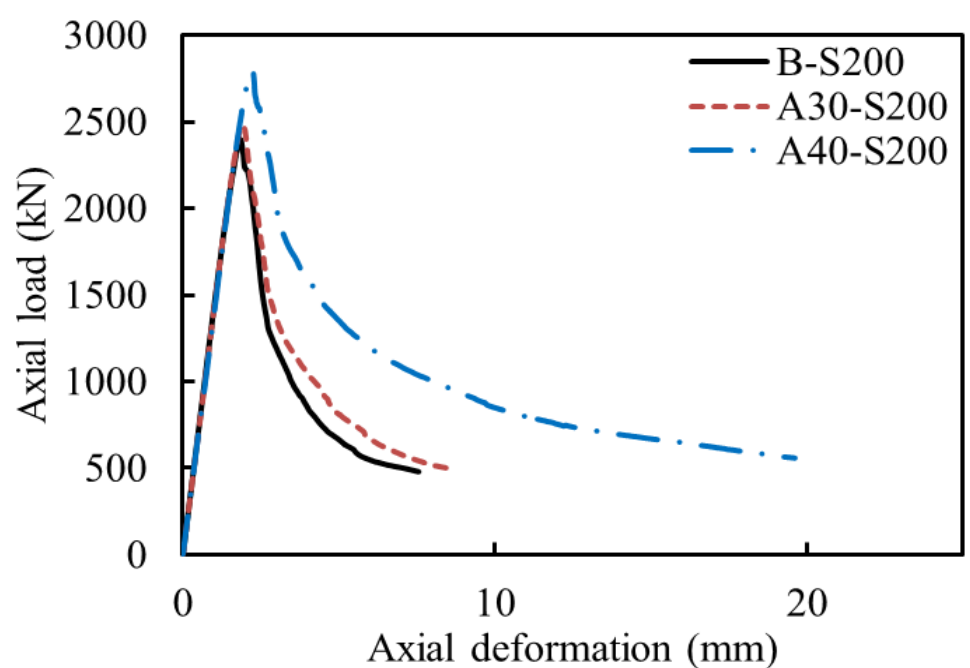

(c)

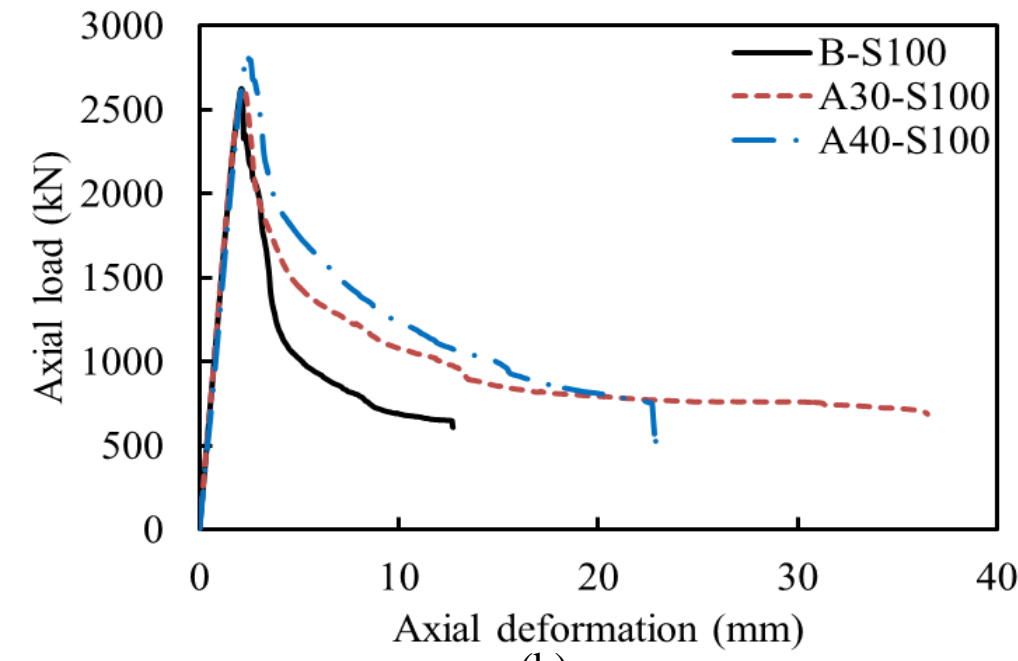

(b)

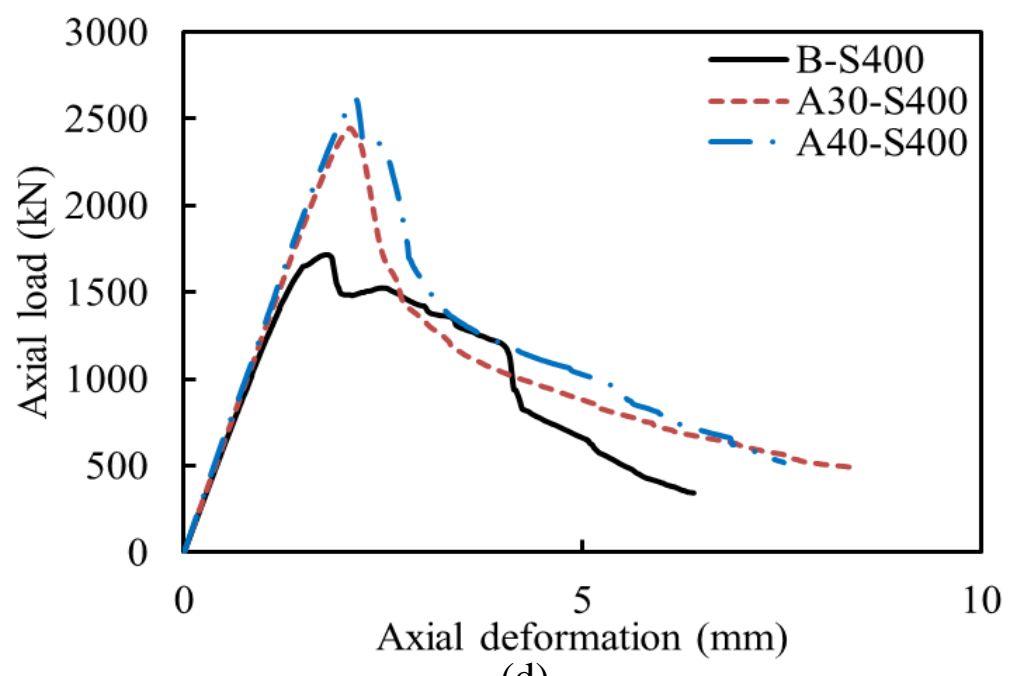

(d)

Fig. 5-Axial load-axial deformation response of column specimens with tie spacing: (a) $50 \mathrm{~mm}$; (b) $100 \mathrm{~mm}$; (c) $200 \mathrm{~mm}$; and (d) $400 \mathrm{~mm}$.

(Note: $1 \mathrm{kN}=0.2248 \mathrm{kip} ; 1 \mathrm{~mm}=0.0393 \mathrm{in}$.) 


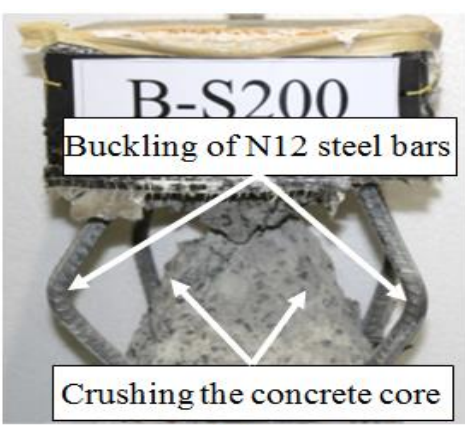

(a)

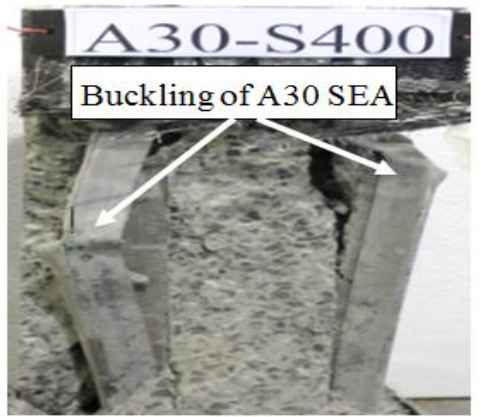

(d)

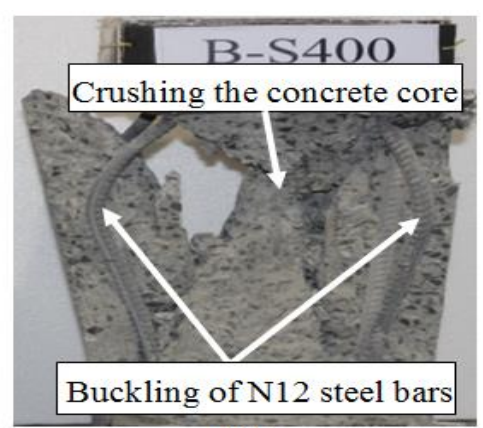

(b)

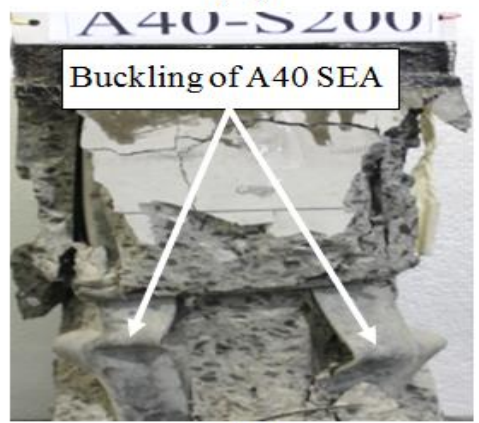

(e)

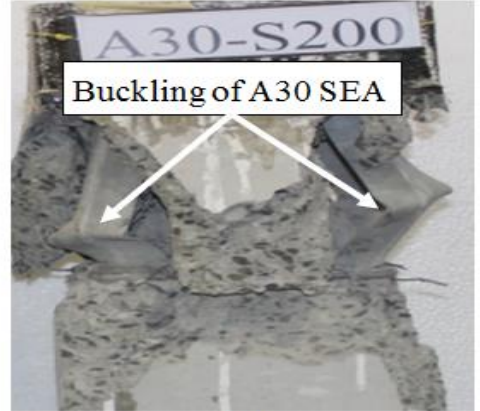

(c)

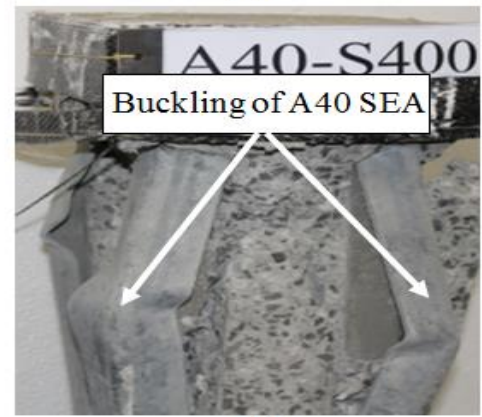

(f)

Fig. 6-Close-up views of the failure modes of column specimens (a) B-S200; (b) B-S400; (c) A30-S200; (d) A30-S400; (e) A40-S200; and (f) A40-S400. 


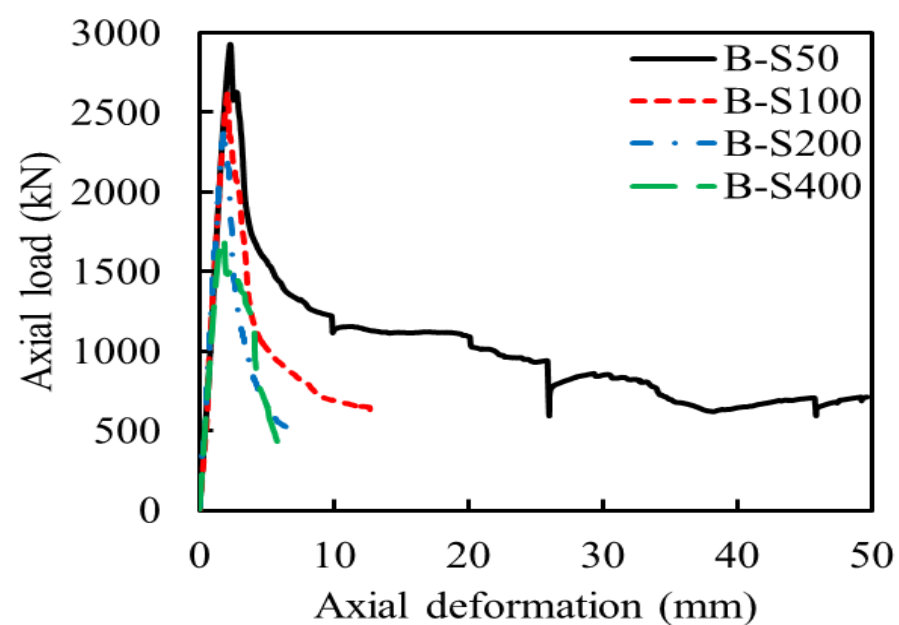

(a)

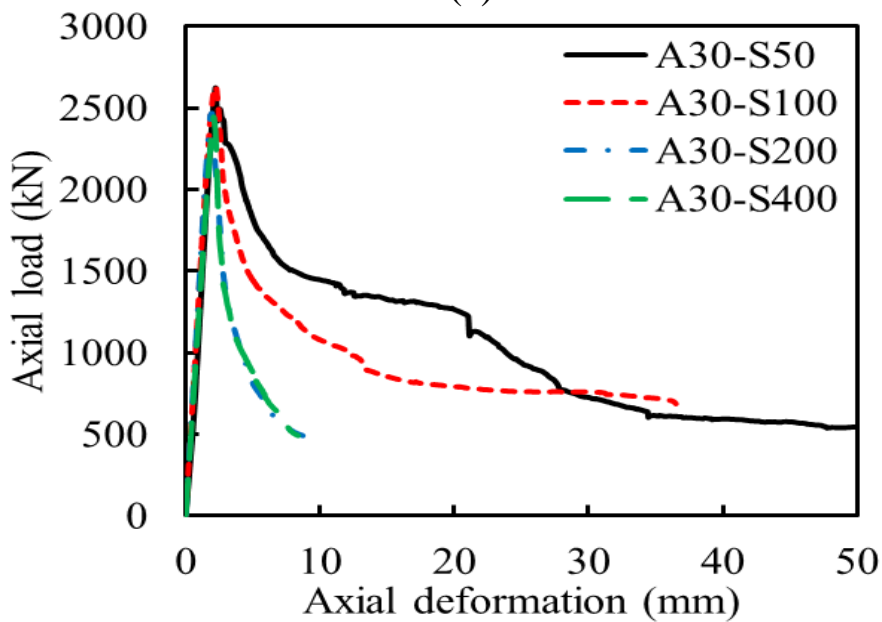

(b)

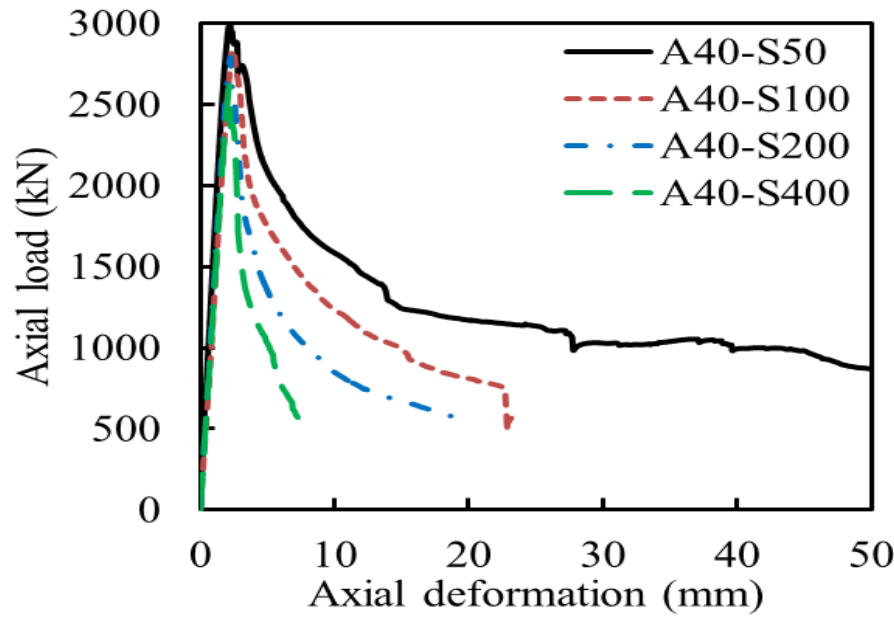

(c)

Fig. 7-Axial load-axial deformation response: (a) Group B specimens; (b) Group A30 specimens; and (c) Group A40 specimens. (Note: $1 \mathrm{kN}=0.2248 \mathrm{kip} ; 1 \mathrm{~mm}=0.0393 \mathrm{in}$.) 